\title{
Anatomical variation of the alveolar inferior nerve: a case report
}

\author{
AZEREDO, R. A. ${ }^{1}$, CESCONETTO, L. A. ${ }^{2 *}$ and TORRES, L. H. S. ${ }^{2}$ \\ ${ }^{1}$ Departament of Morphlogy, Health Science Center, Universidade Federal do Espírito Santo - UFES, \\ Av. Marechal Campos, 1468 - térreo, CEP 29043-900, Vitória, ES, Brazil \\ ${ }^{2}$ Health Science Center, Universidade Federal do Espírito Santo - UFES, \\ Av. Marechal Campos, 1468 - térreo, CEP 29043-900, Vitória, ES, Brazil \\ *E-mail: lorenzzodac@hotmail.com
}

\begin{abstract}
Introduction: The mandibular nerve is the third and inferior division of the trigeminal nerve. One of its branches, the inferior alveolar nerve, is one among the three branches of the posterior division of the mandibular nerve, it supplies the lower jaw and teeth. However, variations of the inferior alveolar nerve branches have been of major concern in the performance of surgical procedure and anesthesia in dental and maxillofacial practice. Method and Results: A variant branch arising from the alveolar inferior nerve before it enters in the mandibular foramen were discovered during a dissection routine. The branch can be described as a variation referring to inferior alveolar nerve as a recurrent branch towards superior, posterior and medial entering in the lateral pterygoid muscle, leaving inferior alveolar nerve before the nerve for mylohyoid muscle. The nerve were found in the in both infratemporal fossa. Conclusion: Knowledge of the variations of the mandibular nerve, its branches and communications are clinically important especially for dental surgeons to understand the effectiveness of the nerve block and complications following regional anesthesia.
\end{abstract}

Keywords: anatomical variations, inferior alveolar nerve, lateral pterygoid muscle.

\section{Introduction}

The mandibular nerve is the third and inferior division of the trigeminal nerve. Unlike the ophthalmic and maxillary divisions, which contain only afferent fibers, the mandibular division contains both afferent and efferent fibers (GUIMARÃES, PONTES, REZENDE et al., 2014). Prakashchandra, Satheesha and Melanie (2014) describe that the Inferior alveolar nerve (IAN) is one among the three branches of the posterior division of the mandibular nerve and it supplies the lower jaw and teeth.

Several studies reported that the IAN nerve can give multiple (extraosseous) branches before it enters the mandibular canal. Within the bony canal it may give rise to multiple intraosseous branches also (RODELLA, BUFFOLI, LABANCA et al., 2012). These anatomical variations of the IAN branches have been of major concern in the performance of surgical procedure and anesthesia in dental and maxillofacial practice (MIZBAH, GERLACH, MAAL et al., 2012)

The aim of this present study was to describe a rare variant branch of the alveolar inferior nerve and discuss its clinical and anatomical implication/importance.

\section{Case Report}

The cadaver used in this report belongs to Dentistry Course Collection of the Federal University of Espirito Santo and this study was submitted to the Ethics Committee of this University, according to the 887.215 protocol number.

During the dissection of the infratemporal fossa, a cut of the zygomatic arch in zigomtico-maxillary suture region was made and reflected for posterior together with the masseter muscle. Then, was made a cut in the coronoid process of the mandible, reflected to upper along with the insertion the temporal muscle exposing the infratemporal fossa, making visible the lateral pterygoid muscle and the anatomical structures related to it. After the identification of the structures, the presence of an anatomical variation related to the inferior alveolar nerve was seen.

A branch arising from the AIN before it enters in the mandibular foramen were discovered. The variant branch can be described as a variation referring to IAN as a recurrent branch towards superior, posterior and medial entering in the Lateral Pterygoid Muscle (LPM), leaving IAN before the nerve for mylohyoid muscle (Figure 1). The nerve were found in the in both infratemporal fossa. The other structures, such as nerve and arteries from the infratemporal fossa were found in normal pattern (GUTIERREZ, GROSSMANN, 2010).

\section{Discussion}

Anatomical knowledge is essential for a diagnosis and treatment of maxillofacial disease. There are several explanations and suggest to anatomic variation, such as migration of neuroblasts and myoblasts in this area during embryogenesis (MURALEEDHARAN, VEERAMANI and CHAND, 2014).

Earlier reports (RANSCHT and BRONNER-FRASER, 1991; BRONNER-FRASER, 1993) affirm that the mandibular nerve and its branches develop from the neural crest cells in the head region, which migrate ventrally through the mesoderm of the first pharyngeal arch which is thought to be influenced by $F$-spondin and T-cadherin (liberated from the caudal somites). Variable levels in these molecules might lead to the 


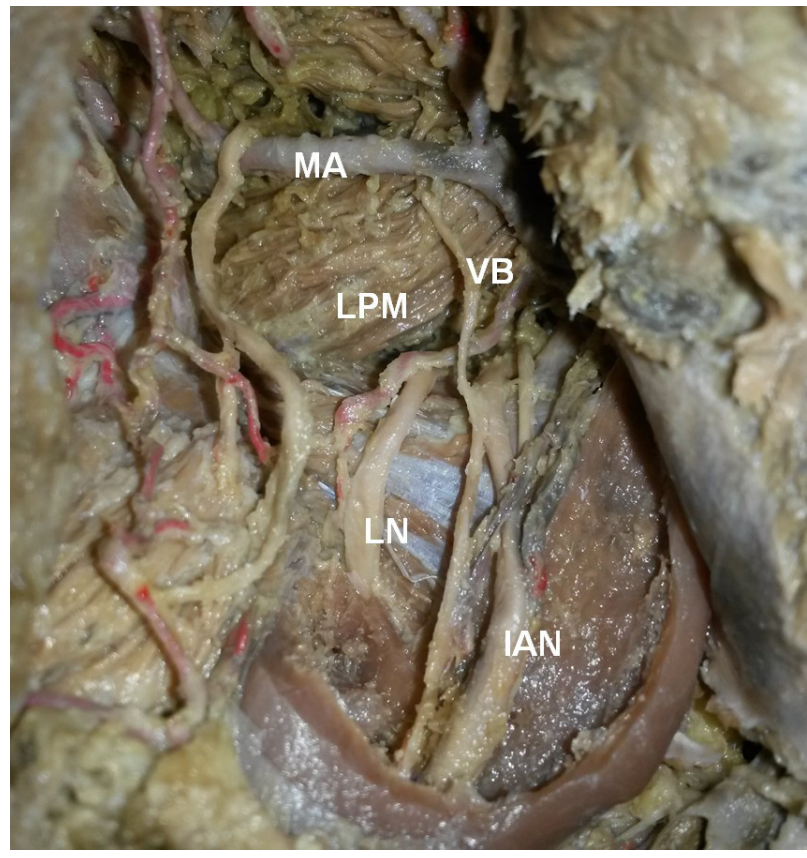

Figure 1. Lateral view of the left infratemporal fossa showing a Variant Branch (VB) from the Inferior Alveolar Nerve (IAN) to the Lateral Pterygoid Muscle (LPM). (MA) Maxillary Artery; (LN) Lingual Nerve.

variations in these nerves. Based on the above knowledge of embryogenesis, abnormal or reverse migration of the neural crest cells could be postulated as a possible reason for the recurrent variant branch seen in this case.

Variations related to IAN, lingual nerve, auriculotemporal nerve have been documented (SABNIS, 2013). Quadros, Roy and D'Souza (2014) and Eustáquio-Silva (2012) also noticed the presence of a colateral brach on infratemporal path of AIN. This variation, in most cases, goes to LPM, or even to join the anterior or posterior division of mandibular nerve.

Several studies (RODELLA, BUFFOLI, LABANCA et al., 2012 ) have shown that before entering the mandible, IAN can give multiple branches which are usually associated with accessory mandibular foramina and mandibular canals. Nevertheless, as reported by Muraleedharan, Veeramani and Chand (2014), in most cases where there are no associated accessory foramina, such branches innervate the LPM. In some cases this additional branch from IAN penetrates the LPM after supplying it to join the main trunk of mandibular nerve, its divisions or any of its branches. In this case, no foramina was found in the jaw and the recurrent branch joins to the lower head of the LPM.

In agreement with our study, Buch and Agnihotri (2012) reported several cases of a variant nerve from the IAN supplying the upper and the lower head of the lateral pterygoid muscle. Concerning to composition, the variation may contain motor portion (Special visceral efferent) and/or sensory (afferent somatic General). The motor fibers supplying the LPM are additional to its usual innervation and in some cases is quite rich (DUBRUL, 1988).

Buch and Agnihotri (2012) claim that the variant nerve may be influenced by infections and malignancies involving fascial spaces particularly pterygomandibular and infratemporal spaces. Furthermore, the variant nerve is in the pathway of
Gow-Gates and Vazirani-Akinosi techniques of the inferior alveolar nerve block (IANB) and consequently may be traumatized during the procedure. On the other hand, if conventional (Halstead) technique of the IANB fails, the use of Gow-Gates technique which anesthetizes several branches of the mandibular nerve including the inferior alveolar nerve, should also take care of the variant branch, if it is present (HOLLIDAY and JACKSON, 2011).

Studies by Anil, Peker, Turgut et al. (2003) and Palti, Almeida, Rodrigues et al. (2011) report the importance of knowledge about the position and course of the IAN and its possible branches becomes important not only for an adequate local anesthesia, but also for dental treatments, oncology and reconstructive surgeries.

The alveolar inferior nerve block is most often used technique for local anesthesia when surgical and restorative procedures in the mandible. Anatomical variations that are almost always present during his studies of human parts. Therefore, it should be emphasized the importance of documenting them in the literature.

Knowledge of the variations of the mandibular nerve, its branches and communications are clinically important especially for dental surgeons to understand the effectiveness of the nerve block and complications following regional anesthesia.

The presence of such variations especially those that include the infratemporal region is of the highest importance for dental surgeons and bucomaxilofacials surgeons for being an area of great acting of these professionals. Due changes in normality can generate unforeseen, cause iatrogenic events or even prevent the realization of certain surgical procedures.

\section{References}

ANIL, A., PEKER, T., TURGUT, HB., GÜLEKON, IN. and LIMAN, F. Variations in the anatomy of the inferior alveolar nerve. British Journal of Oral \& Maxillofacial Surgery, 2003, vol. 41, n. 4, p. 236-239. PMid:12946665. http://dx.doi.org/10.1016/S02664356(03)00113-X.

BRONNER-FRASER, M. Environmental influences on neural crest cell migration. Journal of Neurobiology, 1993, vol. 24, n. 2, p. 233247. PMid:8445389. http://dx.doi.org/10.1002/neu.480240209.

BUCH, A. and AGNIHOTRI, AG. A recurrent variant branch of the inferior alveolar nerve: is it unique? Clinical Anatomy (New York, N.Y.), 2012, vol. 25, n. 4, p. 437-443. PMid:22302685. http:// dx.doi.org/10.1002/ca.22040.

DUBRUL, EL. Sicher and DuBrul's oral anatomy. 8th ed. St. Louis: Ishiyaku EuroAmerica, 1988. 369 p.

EUSTÁQUIO-SILVA, R. Estrutura do nervo alveolar inferior em fetos humanos da $19^{\circ}$ a $36^{\circ}$ semana de vida intrauterina. São Paulo: Faculdade de Medicina Veterinária e Zootecnia; Universidade de São Paulo, 2012. 161 p. [Tese de Doutorado em Ciências].

GUimarÃES, DM., PONTES, FS., REZENDE, DSM. and PONTES, HA. Anatomical variation of mandibular canal simulating a recurrence of odontogenic tumor. Annals of Maxillofacial Surgery, 2014, vol. 4, n. 1, p. 107-109. PMid:24987611. http://dx.doi. org/10.4103/2231-0746.133088.

GUTIERREZ, LMO. and GROSSMANN, E. Anatomofisiologia do músculo pterigóideo lateral. Revista Dor, 2010, vol. 11, n. 3, p. $249-253$.

HOLLIDAY, R. and JACKSON, I. Superior position of the mandibular foramen and the necessary alterations in the local anaesthetic technique: a case report. British Dental Journal, 2011, vol. 210, n. 5, p. 207 211. PMid:21394145. http://dx.doi.org/10.1038/sj.bdj.2011.145. 
MIZBAH, K., GERLACH, N., MAAL, TJ., BERGÉ, SJ. and MEIJER, GJ. The clinical relevance of bifid and trifid mandibular canals. Oral and Maxillofacial Surgery, 2012, vol. 16, n. 1, p. 147-151. PMid:21698363. http://dx.doi.org/10.1007/s10006-011-0278-5.

MURALEEDHARAN, A., VEERAMANI, R. and CHAND, P. Variations in the branching pattern of posterior division of mandibular nerve: a case report. Surgical and Radiologic Anatomy, 2014, vol. 36, n. 9, p. 947-950. PMid:24972574. http://dx.doi.org/10.1007/ s00276-014-1329-z.

PALTI, DG., ALMEIDA, CM., RODRIGUES, AC., ANDREO, JC. and LIMA, JE. Anesthetic technique for inferior alveolar nerve block: a new approach. Journal of Applied Oral Science, 2011, vol. 19, n. 1, p. 11-15. PMid:21437463. http://dx.doi.org/10.1590/ S1678-77572011000100004.

PRAKASHCHANDRA, S., SATHEESHA, BN. and MELANIE, RD. Abnormal communications of the inferior alveolar nerve with anterior division of the mandibular nerve and the lingual nerve: a case report. Journal of Surgical Academia, 2014, vol. 4, n. 2, p. 38-40.
QUADROS, LS., ROY, PA. and D'SOUZA, AS. Inferior alveolar nerve with multiple roots. British Biomedical Bulletin, 2014, vol. 2, n. 1, p. 26-30.

RANSCHT, B. and BRONNER-FRASER, M. T-cadherin expression alternates with migrating neural crest cells in the trunk of the avian embryo. Development, 1991, vol. 111, n. 1, p. 15-22. PMid:1707785.

RODELLA, LF., BUFFOLI, B., LABANCA, M. and REZZANI, R. A review of the mandibular and maxillary nerve supplies and their clinical relevance. Archives of Oral Biology, 2012, vol. 57, n. 4, p. 323-334. PMid:21996489. http://dx.doi.org/10.1016/j. archoralbio.2011.09.007.

SABNIS, AS. A case report on additional branch of mandibular nerve. International Journal of Anatomical Variations, 2013, vol. 6, n. 6, p. 197-198.
Received October 6, 2015 Accepted November 11, 2016 